\title{
Spatio-Temporal Variability and Trends of Penman-Monteith Reference Evapotranspiration (FAO-56) in 1971-2010 under Climatic Conditions of Poland
}

\author{
Leszek Łabędzki*, Bogdan Bąk, Karolina Smarzyńska \\ Institute of Technology and Life Sciences, Kujawsko-Pomorski Research Center, \\ Glinki 60, 85-174 Bydgoszcz, Poland \\ Received: 23 June 2014 \\ Accepted: 8 July 2014
}

\begin{abstract}
The trends of the seasonal (April-September) and monthly reference evapotranspiration time series were analyzed using linear regression. In addition, the trends of air temperature and sunshine hours also were investigated to show possible causes of the increase in reference evapotranspiration. The spatial variability of reference evapotranspiration was lower than the temporal variability and is similar to the spatial distribution of precipitation in the area of Poland. The highest reference evapotranspiration was recorded in the region with the lowest rainfall. The statistically significant linear increasing trends of reference evapotranspiration were determined at each analyzed station in 1971-2010. The increase in the growing season sum of reference evapotranspiration, averaged over 18 stations, was $30 \mathrm{~mm}$ per 10 years. The significant increase in reference evapotranspiration can be explained by the statistically significant increasing trends of air temperature and sunshine hours.
\end{abstract}

Keywords: evapotranspiration, crop water requirement, irrigation, observed trend, climate change

\section{Introduction}

In agriculture crop water use is determined by crop evapotranspiration. Reference, potential, and actual evapotranspiration are distinguished. The potential evapotranspiration of a given crop is defined as soil evaporation and plant transpiration under unlimited soil water supply and actual meteorological conditions. The actual evapotranspiration is the amount of water transpired from plants and evaporated from soil surface under actual meteorological conditions and under non-optimal soil, biological, management, and environmental conditions. The evapotranspiration from a reference surface is called the reference evapo-

*e-mail: 1.labedzki@itp.edu.pl transpiration $\left(\mathrm{ET}_{\mathrm{o}}\right)$. A large uniform grass (or alfalfa) field is considered worldwide as reference surface. The only factors affecting $\mathrm{ET}_{\mathrm{o}}$ are climatic parameters. $\mathrm{ET}_{\mathrm{o}}$ is an agroclimatic parameter and can be computed from weather data. $\mathrm{ET}_{\mathrm{o}}$ expresses the evaporating power of the atmosphere at a specific location and time of the year and does not consider crop and soil factors [1].

Reference evapotranspiration is an important agrometeorological parameter for climatological and hydrological studies, as well as for irrigation planning and management. Reference evapotranspiration can be used to calculate actual evapotranspiration from cropped surfaces other than the reference surface with the crop factor method using the crop coefficient (under standard conditions) and water stress coefficient (under soil water stress conditions). 
To estimate crop water requirements, one can relate potential evapotranspiration from the cropped soil with an optimum water supply to an estimated reference evapotranspiration by means of a crop coefficient.

The FAO Penman-Monteith (FAO-56 or FAO-PM) method has been considered a universal standard to estimate $\mathrm{ET}_{\mathrm{o}}$ [1-3]. There are many researchers who carried out analysis of the FAO-PM method and the reference evapotranspiration calculated with this method. Buttafuoco et al. [4], McVicar et al. [5], and Song et al. [6] analyzed spatial distribution of reference evapotranspiration in different regions and scales. Allen et al. [7, 8], Buttafuoco et al. [4], and Fitzmaurice and Beswick [9] investigated accuracy and sensivity of the FAO-PM method. Popova et al. [10] analyzed the accuracy of different procedures to estimate missing data required in the FAO Penman-Monteith method in reference to southern Bulgaria. Maulé et al. [11], Paltineanu et al. [12], and Sumner and Jacobs [13] analyzed the FAOPM method in relation to other methods of calculating reference evapotranspiration.

There are also many studies on the impact of climate change on observed meteorological elements, mostly temperature and precipitation, but long-term changes in reference evapotranspiration have rarely been explored. In this study, an attempt is made to examine the spatio-temporal variability and trends of the Penman-Monteith reference evapotranspiration in Poland in 1971-2010. It was also important to discover whether trends of temperature and sunshine as the main factors determining evapotranspiration coincide with the trends of reference evapotranspiration.

\section{Methods and Materials}

By defining the reference crop as an actively growing and well watered green grass surface with a height of 0.12 $\mathrm{m}$ having a surface resistance of $70 \mathrm{~s} \cdot \mathrm{m}^{-1}$ and an albedo of 0.23 , reference evapotranspiration was calculated from the Penman-Monteith equation as [1]:

$$
E T_{o}=\frac{0.408 \Delta R_{n}+\gamma \frac{900}{T+273} u\left(e_{s}-e_{a}\right)}{\Delta+\gamma(1+0.34 u)}
$$

...where:

$E T_{\mathrm{o}}-$ reference evapotranspiration $\left(\mathrm{mm} \cdot \mathrm{day}^{-1}\right)$

$R_{n}$ - net radiation $\left(\mathrm{MJ} \cdot \mathrm{m}^{-2} \cdot \mathrm{day}^{-1}\right)$

$T$ - mean daily air temperature at $2 \mathrm{~m}$ height $\left({ }^{\circ} \mathrm{C}\right)$

$u$ - wind speed at $2 \mathrm{~m}$ height $\left(\mathrm{m} \cdot \mathrm{s}^{-1}\right)$

$e_{s}$ - saturation vapour pressure $(\mathrm{kPa})$

$e_{a}$ - actual vapour pressure $(\mathrm{kPa})$

$\Delta$ - slope of the vapour pressure curve $\left(\mathrm{kPa} \cdot{ }^{\circ} \mathrm{C}^{-1}\right)$

$\gamma \quad$ - psychrometric constant $\left(\mathrm{kPa}^{\circ}{ }^{\circ} \mathrm{C}^{-1}\right)$.

For the purpose of this study $\mathrm{ET}_{\mathrm{o}}$ was calculated with a 10-day time step using mean 10-day weather data. Several data in Equation (1) were not measured directly and they were computed. The methods of computation of such data used in the study are presented in details by Łabędzki et al. $[14,15]$.
Table 1. Geographical location of the studied meteorological stations.

\begin{tabular}{|c|c|c|c|c|}
\hline No. & Station & $\begin{array}{l}\text { Altitude } \\
\text { (m a.s.l.)* }\end{array}$ & Latitude & Longitude \\
\hline 1 & Białystok & 139 & $53^{\circ} 13^{\prime}$ & $23^{\circ} 10^{\prime}$ \\
\hline 2 & Biebrza & 117 & $53^{\circ} 39^{\prime}$ & $22^{\circ} 36^{\prime}$ \\
\hline 3 & Bydgoszcz & 46 & $53^{\circ} 08^{\prime}$ & $18^{\circ} 01^{\prime}$ \\
\hline 4 & Częstochowa & 261 & $50^{\circ} 49^{\prime}$ & $19^{\circ} 06^{\prime}$ \\
\hline 5 & Elbląg & 38 & $54^{\circ} 10^{\prime}$ & $19^{\circ} 26^{\prime}$ \\
\hline 6 & Gorzów & 65 & $52^{\circ} 44^{\prime}$ & $15^{\circ} 15^{\prime}$ \\
\hline 7 & Kielce & 256 & $50^{\circ} 51^{\prime}$ & $20^{\circ} 37^{\prime}$ \\
\hline 8 & Koszalin & 33 & $54^{\circ} 12^{\prime}$ & $16^{\circ} 09^{\prime}$ \\
\hline 9 & Kraków & 209 & $50^{\circ} 04^{\prime}$ & $19^{\circ} 57^{\prime}$ \\
\hline 10 & Lublin & 171 & $51^{\circ} 14^{\prime}$ & $22^{\circ} 34^{\prime}$ \\
\hline 11 & Łódź & 184 & $51^{\circ} 44^{\prime}$ & $19^{\circ} 24^{\prime}$ \\
\hline 12 & Mława & 141 & $53^{\circ} 06^{\prime}$ & $20^{\circ} 21^{\prime}$ \\
\hline 13 & Opole & 176 & $50^{\circ} 40^{\prime}$ & $17^{\circ} 58^{\prime}$ \\
\hline 14 & Poznań & 86 & $52^{\circ} 25^{\prime}$ & $16^{\circ} 50^{\prime}$ \\
\hline 15 & Rzeszów & 200 & $50^{\circ} 06^{\prime}$ & $22^{\circ} 03^{\prime}$ \\
\hline 16 & Szczecin & 1 & $53^{\circ} 24^{\prime}$ & $14^{\circ} 37^{\prime}$ \\
\hline 17 & Warszawa & 106 & $52^{\circ} 09^{\prime}$ & $20^{\circ} 59^{\prime}$ \\
\hline 18 & Wrocław & 116 & $51^{\circ} 06^{\prime}$ & $17^{\circ} 05^{\prime}$ \\
\hline
\end{tabular}

*m a.s.l. - meters above mean sea level

$\mathrm{ET}_{\mathrm{o}}$ was calculated in the growing period (AprilSeptember) of 1971-2010 for each month and the whole period. Using Equation (1) the mean 10(11)-day values of $\mathrm{ET}_{\mathrm{o}}$ were calculated using 10(11)-day-averages of $R_{n}, T, u$, $e_{s}$, and $e_{a}$. Then the 10(11)-day sums of $\mathrm{ET}_{\mathrm{o}}$ were calculated by multiplying the mean 10(11)-day values by 10 or 11 . The monthly and the whole period sums were computed as the sums of the 10(11)-day sums.

The daily records of meteorological parameters came from select meteorological stations located in different regions of Poland (Table 1, Fig. 1). The stations are kept by the Institute of Meteorology and Water Management (stations Nos. 1 and 4-18) and by the Institute of Technology and Life Sciences (stations Nos. 2 and 3). The measured meteorological parameters include air temperature, air humidity, sunshine hours, and wind velocity.

The statistical analysis was performed to get the values of mean, minimum, maximum, standard deviation, variability coefficient, and median. Statistical parameters characterizing the temporal variability of $\mathrm{ET}_{\mathrm{o}}$ are determined using $\mathrm{ET}_{\mathrm{o}}$ averaged over 18 stations in each year. Statistical parameters characterizing the spatial variability of $\mathrm{ET}_{\mathrm{o}}$ are determined using $\mathrm{ET}_{\mathrm{o}}$ averaged over 40 years at each station.

Trends of $\mathrm{ET}_{\mathrm{o}}$ in the 40-year time series were established to check if reference evapotranspiration has 
increased or decreased significantly in 1971-2010. Linear trends were fitted using ordinary least squares regression. The trends were computed for individual stations and for average $\mathrm{ET}_{\mathrm{o}}$ over all stations, in each month from April to September and in the whole period. The statistical significance of the trends was assessed at the 5\% level using the t-test. The main statistical parameter drawn from the regression analysis, the slope, indicates the mean temporal change of the studied variable. Positive values of the slope show increasing trends, while negative values indicate decreasing trends. The total change during the period under observation is obtained by multiplying the slope by the number of years or the change during a decade (10-year period) by multiplying the slope by 10 .

The maps of the spatial distribution of precipitation, temperature, reference evapotranspiration, and its trend parameters were created using the Regularized Spline Radial Basic Function method with the Spatial Analyst Module of ArcView GIS 9.1.

\section{Results and Discussion}

\section{Climatological Characteristics}

Poland is situated in the Great European Plain between the Baltic Sea and the Carpathian Mountains. It is located in a transitory temperate climate zone, influenced by a mild oceanic climate from the west and a dry continental climate from the east. Climatic conditions in Poland are characterized by considerable variability in weather during long periods of time (years) as well as short periods (days, weeks, months).

The annual precipitation amounts to $600 \mathrm{~mm}$. It reaches $350 \mathrm{~mm}$ on average during the growing period (AprilSeptember). In this period precipitation ranges from 300 $\mathrm{mm}$ in the central part to $400 \mathrm{~mm}$ in northern Poland and to $600 \mathrm{~mm}$ in southern Poland (Fig. 2). The annual mean tem-

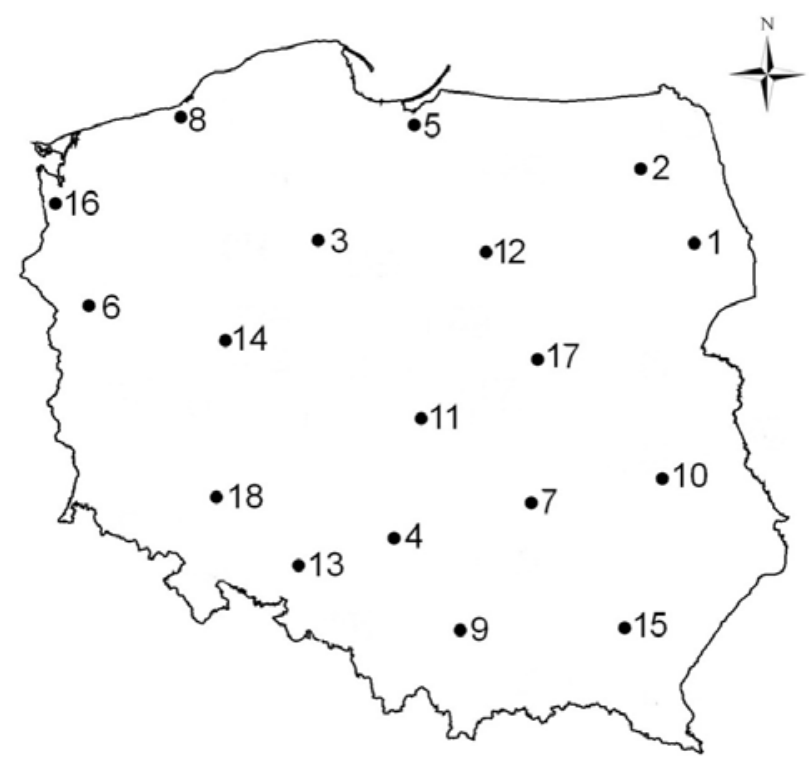

Fig. 1. Geographical location of the studied meteorological stations in Poland (1 - the number of the station from Table 1).

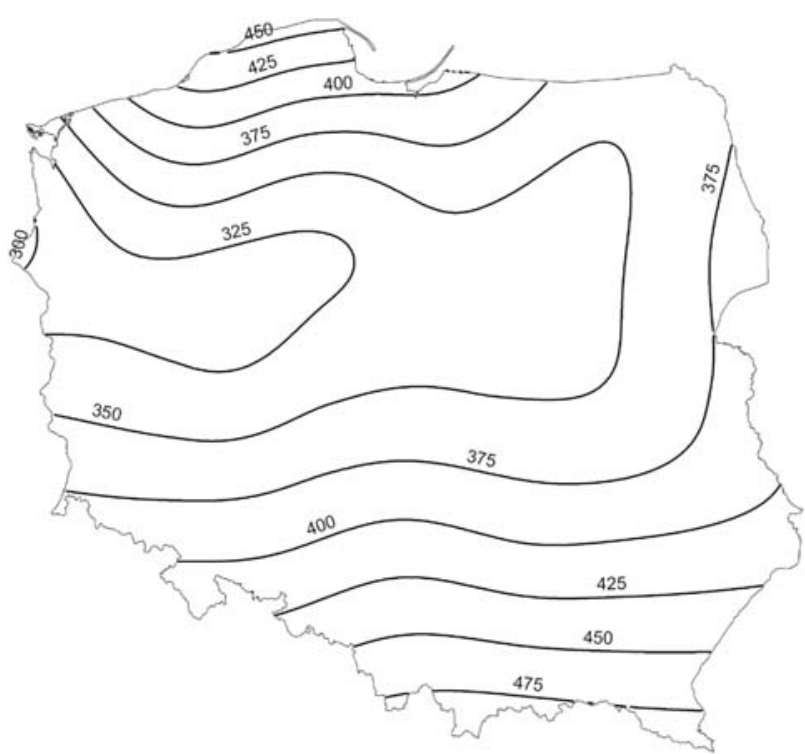

Fig. 2. Precipitation ( $\mathrm{mm}$ ) in the growing season (AprilSeptember), mean values in 1971-2010.

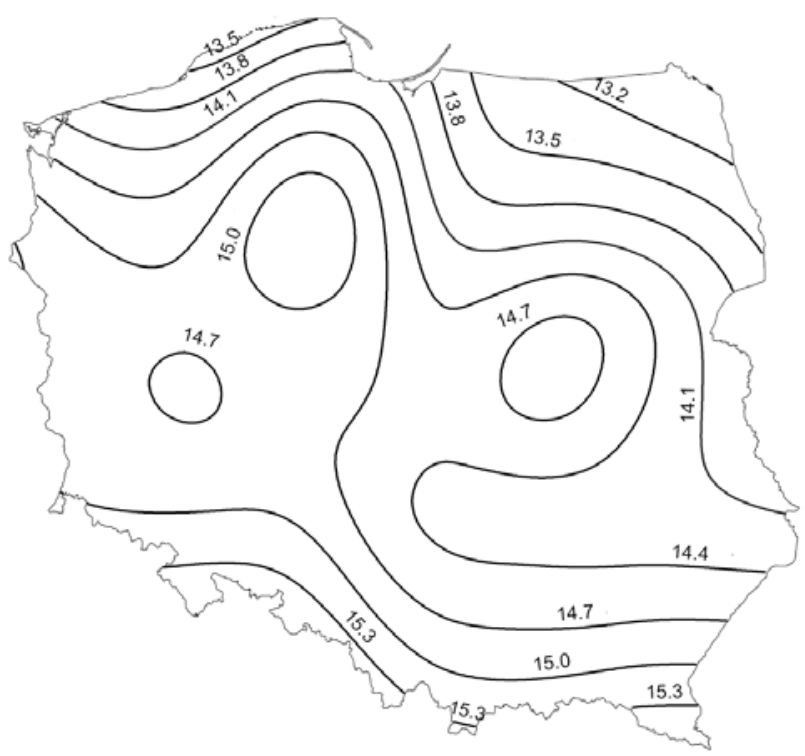

Fig. 3. Temperature $\left({ }^{\circ} \mathrm{C}\right)$ in the growing season (April-September), mean values in 1971-2010.

perature is $7.5^{\circ} \mathrm{C}$ and in the growing season is $14.3^{\circ} \mathrm{C}$ (Fig. 3 ). Averages of temperature in Poland in the $20^{\text {th }}$ century varied from $6^{\circ} \mathrm{C}$ to over $9^{\circ} \mathrm{C}$, with a tendency for 7 -year periodicity and reveal an increasing trend, which means the warming up reaching $0.9^{\circ} \mathrm{C}$ per 100 years [16]. The mean temperature ranges from $-2.5^{\circ} \mathrm{C}$ in January to $18^{\circ} \mathrm{C}$ in July. The daily maximum temperature sometimes rises above $30^{\circ} \mathrm{C}$ in summer.

Due to the shortage of precipitation and the increase trend of temperature, drought frequency has increased, particularly during the last decade. Central, northwestern and mideastern parts are most threatened by droughts. The growing season rainfall amount is often less than $300 \mathrm{~mm}$. This area sometimes experiences extremely long periods without rain. Droughts appear once every 4-5 years in central Poland [17]. Drought usually begins in western Poland, 
Table 2. Statistics of temporal variability of $\mathrm{ET}_{\mathrm{o}}$ averaged over 18 stations.

\begin{tabular}{|l|c|c|c|c|c|c|c|}
\hline \multicolumn{1}{|c|}{ Parameter } & April & May & June & July & Aug. & Sept. & April-Sept. \\
\hline Mean (mm) & 61 & 91 & 103 & 107 & 90 & 52 & 504 \\
\hline Minimum (mm) & 47 & 67 & 77 & 75 & 71 & 41 & 404 \\
\hline Maximum (mm) & 90 & 112 & 134 & 159 & 111 & 68 & 591 \\
\hline Median (mm) & 58 & 92 & 101 & 108 & 90 & 50 & 504 \\
\hline Standard deviation (mm) & 9 & 11 & 14 & 18 & 11 & 8 & 48 \\
\hline Variability coefficient (\%) & 16 & 12 & 14 & 17 & 12 & 15 & 9 \\
\hline
\end{tabular}

Table 3. Statistics of spatial variability of $\mathrm{ET}_{\mathrm{o}}$ averaged over 40 years.

\begin{tabular}{|l|c|c|c|c|c|c|c|}
\hline \multicolumn{1}{|c|}{ Parameter } & April & May & June & July & Aug. & Sept. & April-Sept. \\
\hline Mean (mm) & 61 & 91 & 103 & 107 & 90 & 52 & 504 \\
\hline Minimum (mm) & 53 & 86 & 98 & 99 & 83 & 44 & 468 \\
\hline Maximum (mm) & 64 & 97 & 110 & 113 & 96 & 57 & 531 \\
\hline Median (mm) & 61 & 91 & 103 & 107 & 90 & 53 & 507 \\
\hline Standard deviation (mm) & 3 & 4 & 4 & 4 & 4 & 3 & 21 \\
\hline Variability coefficient (\%) & 5 & 4 & 4 & 4 & 5 & 6 & 4 \\
\hline
\end{tabular}

moves through the central part and eventually reaches the eastern side. Droughts have become a severe problem in Polish agriculture. They are the main reason for the decline in crop yields.

\section{Temporal Variability of Reference Evapotranspiration $\mathrm{ET}_{\mathrm{o}}$}

The monthly and growing season sums of $\mathrm{ET}_{\mathrm{o}}$, averaged over 18 stations, characterize the multi-year mean reference evapotranspiration in Poland. In particular months it ranges from $52 \mathrm{~mm}$ in September to $107 \mathrm{~mm}$ in July (Table 2). This means a mean daily reference evapotranspiration from $1.7 \mathrm{~mm} \cdot$ day $^{-1}$ to $3.5 \mathrm{~mm} \cdot$ day $^{-1}$, respectively. The highest monthly sum $(159 \mathrm{~mm})$ was recorded in July 2006 and the lowest $(41 \mathrm{~mm})$ in September 1978.

In the whole growing period, from April to September, $\mathrm{ET}_{\mathrm{o}}$ amounts to $504 \mathrm{~mm}$. Taking into account the average precipitation in this period equal to $370 \mathrm{~mm}$, water deficit can be expected in Poland, on average. During 1971-2010, the lowest whole-country mean $\mathrm{ET}_{\mathrm{o}}$ (404 mm) occurred in 1980 and the highest $\mathrm{ET}_{\mathrm{o}}(591 \mathrm{~mm}$ ) in 2006 (Table 2). 1980 was a very wet year with the highest precipitation in most regions of Poland, whereas in 2006 severe drought occurred all over the country, caused by very low precipitation, high air temperature, and high insolation. The close relationship between reference evapotranspiration and precipitation is a characteristic feature of a transitory temperate climate. Reference evapotranspiration had rather high temporal variability in the multi-year period, with the vari- ability coefficient of $12-16 \%$ for the monthly sums and $9 \%$ for the sums in the growing season. This is the other special feature of climate in Poland.

$\mathrm{ET}_{\mathrm{o}}$ changed in a wide range in 1971-2010. The amplitude (maximum-minimum) of the $\mathrm{ET}_{\mathrm{o}}$ sums in the growing season was the lowest in northern Poland $(161 \mathrm{~mm})$ and the highest in central Poland $(298 \mathrm{~mm})$. It shows that meteorological conditions were more stable in northern Poland than in central.

\section{Spatial Variability of Reference Evapotranspiration $\mathrm{ET}_{\mathrm{o}}$}

The monthly and the growing season sums of $\mathrm{ET}_{\mathrm{o}}$, averaged over 40 years at each station, characterise the spatial variability of long-term average reference evapotranspiration. The minimum multi-year average $\mathrm{ET}_{\mathrm{o}}$ in the growing season $(468 \mathrm{~mm})$ was recorded at station No. 2, located in the northeastern part of Poland (Table 3). The maximum temporal average sum of $\mathrm{ET}_{\mathrm{o}}(531 \mathrm{~mm})$ was observed in the central part (the station No. 11).

Similar to the spatially averaged $\mathrm{ET}_{0}$, the monthly sums of $\mathrm{ET}_{\mathrm{o}}$, averaged in time, were the highest in July (113 mm) in central Poland and the lowest in September (44 mm) in northeastern part (Table 3).

The spatial variability of reference evapotranspiration (the variability coefficient 4-6\%) was lower than the temporal variability. This means the greater differentation of the reference evapotranspiration within the years than in the space. 
Table 4. Absolute minimum and maximum sums of $\mathrm{ET}_{\mathrm{o}}(\mathrm{mm})$ in the growing season (April-September) at 18 stations in 1971-2010.

\begin{tabular}{|c|c|c|}
\hline Period & Abs min & Abs max \\
\hline April & 36 & 99 \\
\hline May & 55 & 128 \\
\hline June & 68 & 162 \\
\hline July & 61 & 189 \\
\hline August & 60 & 131 \\
\hline September & 31 & 83 \\
\hline April-September & 353 & 694 \\
\hline
\end{tabular}

The absolute minimum reference evapotranspiration sum in the growing season at all stations and in all years amounted to $353 \mathrm{~mm}$ and was determined in 1980 in northeastern Poland (station No. 2) (Table 4). The absolute maximum was equal to $694 \mathrm{~mm}$ in 2006 in central Poland (station No. 17).

A spatial differentiation of the reference evapotranspiration is observed in Poland (Fig. 4). The growing season sum of reference evapotranspiration, calculated with the Penman-Monteith method, ranges in the area of the country from 460 to $530 \mathrm{~mm}$ in an average year. The higher reference evapotranspiration was recorded in central Poland from west to east. The highest values occurred in the area with station Nos. 6, 11, 14, and 17. In comparing with other regions, this is the region of Poland with low rainfall that is most threatened by meteorological droughts. In connection with high reference evapotranspiration the region is threatened by agricultural droughts.

Similar to the sum of the reference evapotranspiration in the growing season, the highest values of the monthly sums occurred in the midwestern part of Poland, reaching $110 \mathrm{~mm}$ in July in that region. The lowest $\mathrm{ET}_{\mathrm{o}}$ is observed in April and September, being twice less than in July.

\section{Trends of Reference Evapotranspiration $\mathrm{ET}_{\mathrm{o}}$}

The linear increasing trends of $\mathrm{ET}_{\mathrm{o}}$ were determined at each analyzed station as well as of the 18-station mean ET in 1971-2010. They are statistically significant at the probability level $\mathrm{p}<0.05$.
Table 5. Trends of mean $\mathrm{ET}_{\mathrm{o}}$ in the growing season (AprilSeptember) at 18 stations in 1971-2010.

\begin{tabular}{|l|c|c|}
\hline \multicolumn{1}{|c|}{ Period } & $\begin{array}{c}\text { Increase } \\
\left(\mathrm{mm}^{-1} \text { decade }^{-1}\right)\end{array}$ & $\begin{array}{c}\text { Determination } \\
\text { coefficient } \mathrm{R}^{2}\end{array}$ \\
\hline April & 5.7 & 0.494 \\
\hline May & 3.6 & 0.151 \\
\hline June & 6.1 & 0.262 \\
\hline July & 7.7 & 0.263 \\
\hline August & 4.3 & 0.211 \\
\hline September & 2.5 & 0.143 \\
\hline April-September & 29.9 & 0.537 \\
\hline
\end{tabular}

The increase in the growing season sum of $\mathrm{ET}_{\mathrm{o}}$, averaged over 18 stations, is $29.9 \mathrm{~mm}$ per 10 years and the determination coefficient of the linear trend $\mathrm{R}^{2}=0.537$ (Table 5, Fig. 5). The trends of the 18-station mean $\mathrm{ET}_{\mathrm{o}}$ are also significant statistically in each month from April to September (Table 5). The greatest increase is observed in July ( $7.7 \mathrm{~mm}$ per 10 years).

The trend of the growing season sum of $\mathrm{ET}_{\mathrm{o}}$ shows the increase of 9-54 mm.decade ${ }^{-1}$ at the analyzed stations (Fig. 6 ). The biggest increase is observed at stations 7 (Warszawa) and 8 (Wrocław), the lowest at station 2 (Bydgoszcz). The spatial distribution of the determination coefficient $\mathrm{R}^{2}$ of the linear trend changes from 0.08 to 0.66 , with highest value at station 7 (Warszawa) and the lowest at station 2 (Bydgoszcz) (Fig. 7). All trends are statistically significant at probability level $\mathrm{p}<0.05$ in the whole growing season and in each month.

The changes of reference evapotranspiration $\mathrm{ET}_{\mathrm{o}}$ in the analyzed 40 years are also seen when taking account the decades (Table 6). In the first decade (1971-80) $\mathrm{ET}_{\mathrm{o}}$ in the growing season was the least $(463 \mathrm{~mm})$. Beginning from 1971 the 10-year mean $\mathrm{ET}_{\mathrm{o}}$ increased permanently, reaching the highest value in 2001-10 (555 mm). This tendency is observed in each month as well as in the whole growing period at each station, except for June, when $\mathrm{ET}_{\mathrm{o}}$ was higher in the 1970s than the 1980s, also at each station.

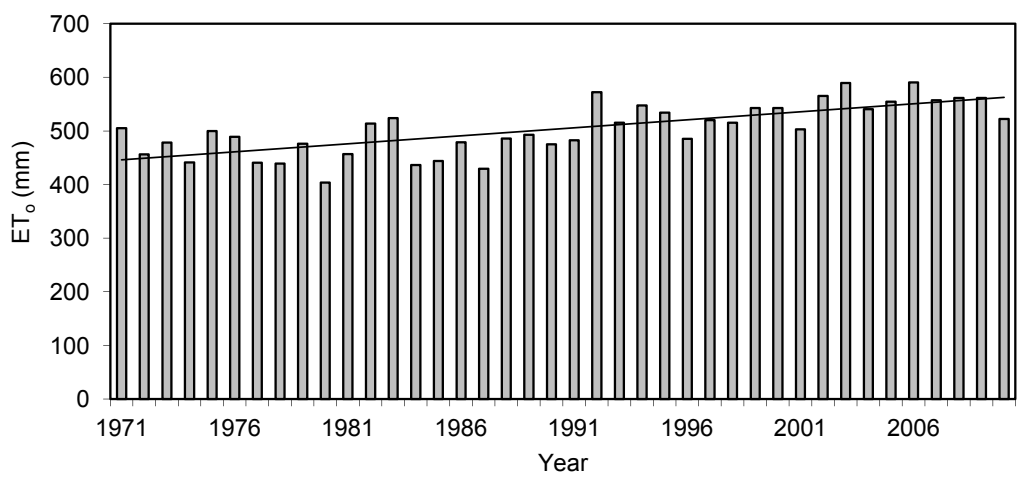

Fig. 5. Linear trend of mean sum of $\mathrm{ET}_{\mathrm{o}}(\mathrm{mm})$ over 18 stations in the growing season (April-September) in 1971-2010. 
Table 6. $\mathrm{ET}_{\mathrm{o}}(\mathrm{mm})$ in the decades of 1971-2010, averaged for 18 stations.

\begin{tabular}{|c|c|c|c|c|c|c|c|}
\hline Years & April & May & June & July & Aug. & Sept. & April-Sept. \\
\hline $1971-1980$ & 53 & 85 & 98 & 95 & 83 & 49 & 463 \\
\hline $1981-1990$ & 57 & 90 & 92 & 101 & 86 & 49 & 474 \\
\hline $1991-2000$ & 64 & 95 & 108 & 111 & 95 & 53 & 526 \\
\hline $2001-2010$ & 69 & 96 & 114 & 121 & 97 & 57 & 555 \\
\hline $1971-2010$ & 61 & 91 & 103 & 107 & 90 & 52 & 504 \\
\hline
\end{tabular}

Table 7. Increase of mean air temperature and mean daily sunshine duration in the growing season (April-September) at 18 stations in 1971-2010.

\begin{tabular}{|c|c|c|c|c|}
\hline \multirow{2}{*}{ Period } & \multicolumn{2}{|c|}{ Temperature } & \multicolumn{2}{c|}{ Sunshine duration } \\
\cline { 2 - 5 } & Increase $\left({ }^{\circ} \mathrm{C} \cdot \mathrm{decade}^{-1}\right)$ & Significance level $(\mathrm{p}$-value) & Increase $\left(\mathrm{h} \cdot\right.$ decade $\left.^{-1}\right)$ & Significance level (p-value) \\
\hline April & 0.75 & $<0.0001$ & 0.61 & $<0.001$ \\
\hline May & 0.28 & 0.174 & 0.37 & 0.048 \\
\hline June & 0.37 & 0.016 & 0.58 & 0.003 \\
\hline July & 0.69 & 0.003 & 0.65 & 0.050 \\
\hline August & 0.45 & 0.006 & 0.33 & 0.027 \\
\hline September & 0.29 & 0.132 & 0.39 & $<0.0001$ \\
\hline April-September & 0.47 & $<0.0001$ & 0.49 & 0.006 \\
\hline
\end{tabular}

The important question to answer in the next stage of the study was about the effect of meteorological variables on $\mathrm{ET}_{\mathrm{o}}$ trends. Reference evapotranspiration process is mainly controlled by variations in air temperature, solar radiation, relative humidity, and wind speed. Tabari et al. [18] showed that the increasing trend in $\mathrm{ET}_{\mathrm{o}}$ at 20 meteorological stations during 1966-2005 in the western half of Iran was mainly caused by a significant increase in air tempera-

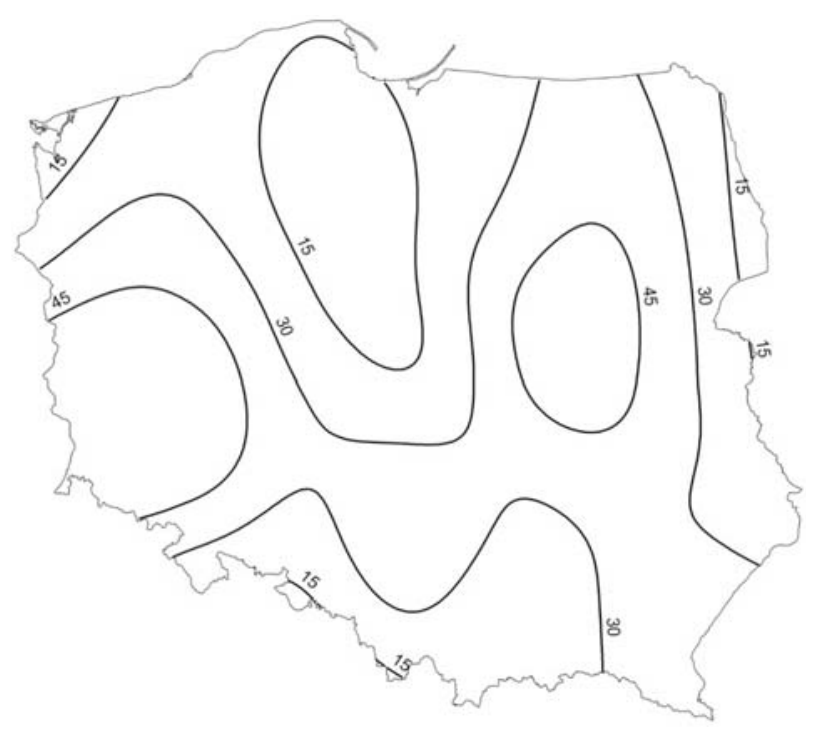

Fig. 6. Increase of $\mathrm{ET}_{\mathrm{o}}\left(\mathrm{mm} \cdot \mathrm{decade}^{-1}\right)$ in the growing season (April-September) in 1971-2010. ture. Analysis of monthly $\mathrm{ET}_{\mathrm{o}}$ at 15 stations during 19612005 in the Taoer River basin in China [19] showed that maximum air temperature, mean air temperature, relative humidity, and bright sunshine hours were main climate variables responsible for the variability in $\mathrm{ET}_{0}$. Vergni and Todisco [20] proved that $\mathrm{ET}_{\mathrm{o}}$ trends in Central Italy were mainly positive and were strictly related to the tendencies in mean temperature and mean temperature range. Espadafor

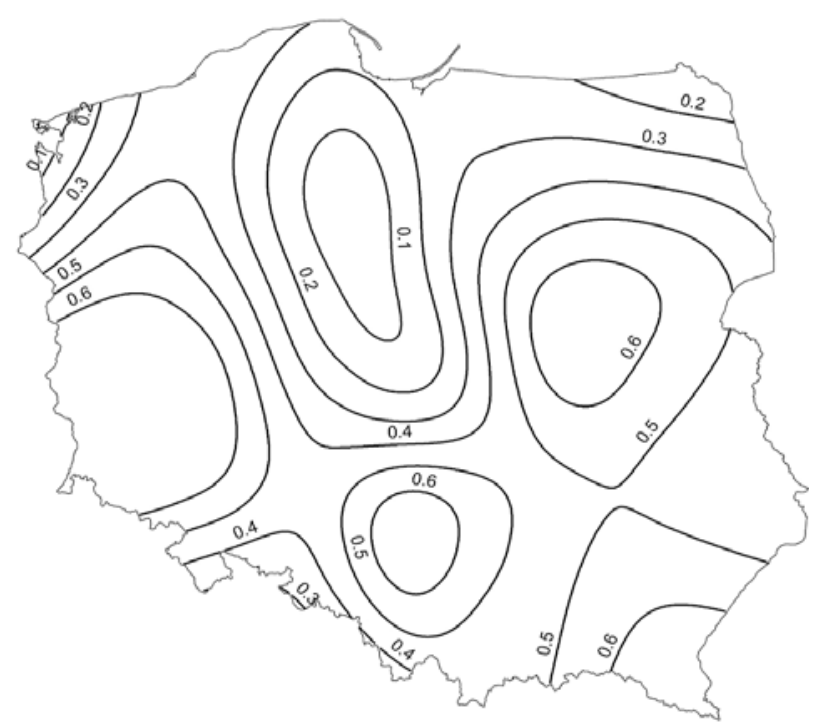

Fig. 7. Determination coefficient $\mathrm{R}^{2}$ of the linear trend of the growing season sum of $\mathrm{ET}_{\mathrm{o}}$ in 1971-2010. 


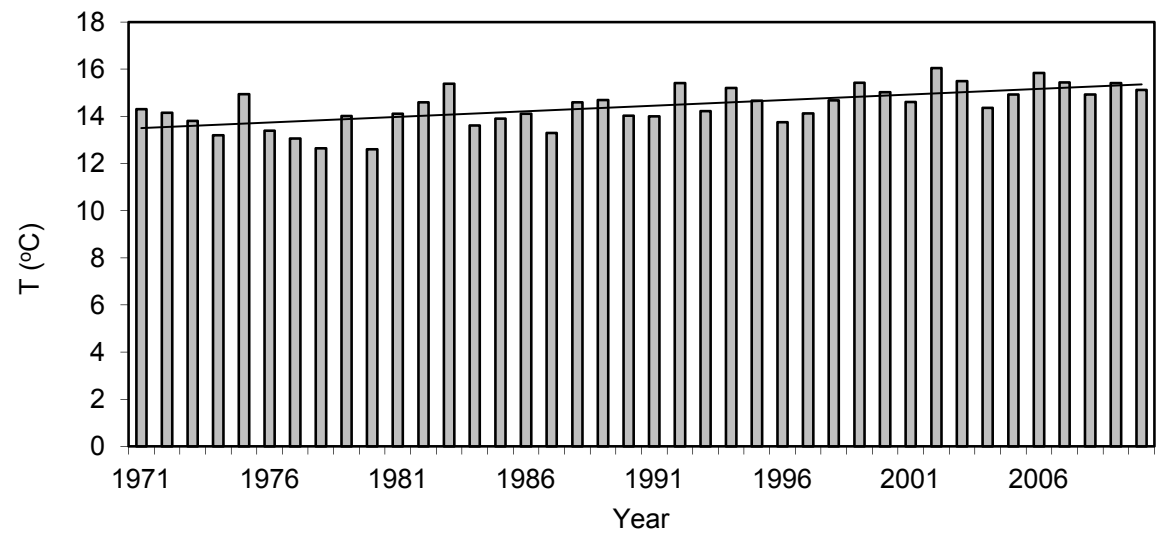

Fig. 8. Linear trend of mean air temperature T $\left({ }^{\circ} \mathrm{C}\right)$ over 18 stations in the growing season (April-September) in 1971-2010.

et al. [21] detected statistically significant increases in PM$\mathrm{ET}_{\mathrm{o}}$ in Southern Spain due to increases in air temperature and solar radiation.

Therefore, possible causes of the increase in the $\mathrm{ET}_{\mathrm{o}}$ series were investigated in view of the trends of the meteorological variables, including air temperature and sunshine hours.

Average air temperature shows a long-term statistically significant increasing trend of $0.47^{\circ} \mathrm{C}$ per 10 years in the growing season (April-September) (Fig. 8). The highest increase is observed in April $\left(0.75^{\circ} \mathrm{C} \cdot\right.$ decade $\left.^{-1}\right)$ and in July $\left(0.69^{\circ} \mathrm{C} \cdot\right.$ decade $\left.^{-1}\right)$; the lowest in May and September, and they were not statistically significant (Table 7).

Sunshine duration also increased significantly in 19712010. Mean daily sunshine hours increased by 0.49 $\mathrm{h} \cdot \mathrm{decade}^{-1}$ when concerning the whole growing period (Fig. 9). The increasing trends of 0.61 and $0.65 \mathrm{~h}$ per 10 years are observed in April and May, respectively. The increase in August was the lowest, not proven statistically (Table 7).

The significant increase in $\mathrm{ET}_{\mathrm{o}}$ is an effect of the increasing trends of air temperature and sunshine hours, observed in the analyzed 40 years in Poland. The observed increase in temperature in Poland in the growing season of 1971-2010 is higher than that related by Beniston and Tol [22] for most of Europe during the $20^{\text {th }}$ century, which amounts to $0.8^{\circ} \mathrm{C}$ in annual mean temperature. Kożuchowski and Żmudzka [16] determined that average temperature in Poland in the $20^{\text {th }}$ century increased $0.9^{\circ} \mathrm{C}$ per 100 years. For Polish conditions Kępińska-Kasprzak et al. [23] showed a significant increase in temperature and sunshine hours in one region of the country (Wielkopolska) during 1966-85, effecting the increase of reference evaporation. The observed trend in increased temperature in Poland is in good agreement with trends observed in other European countries. An overview of climatic trends in Germany [24] shows that the annual average temperature increased by $1.1^{\circ} \mathrm{C}$ between 1981 and 2000. Mladenova and Varlev [25] noted in 1970-2000 an increase in the average temperature sum in the vegetation period by about $200^{\circ} \mathrm{C}$ in Bulgaria, which meant about $1^{\circ} \mathrm{C}$ of mean temperature. Ljubenkov [26] has proved that in Korčula Island in Croatia temperature had an upward trend in 1948-2008 with an increase of about $1.0^{\circ} \mathrm{C}$ in 60 years.

\section{Conclusions}

This paper has concentrated on spatial and temporal variability of Penman-Monteith reference evapotranspiration in Poland in 1971-2010. Using 10-day weather data from 18 weather stations, the PM reference evapotranspiration was calculated. The analysis of temporal and spatial variability of the PM reference evapotranspiration was made. The trends of the seasonal (April-September) and monthly reference evapotranspiration time series were analyzed with linear regression during 1971-2010. In addition, the trends of air temperature and sunshine hours were also

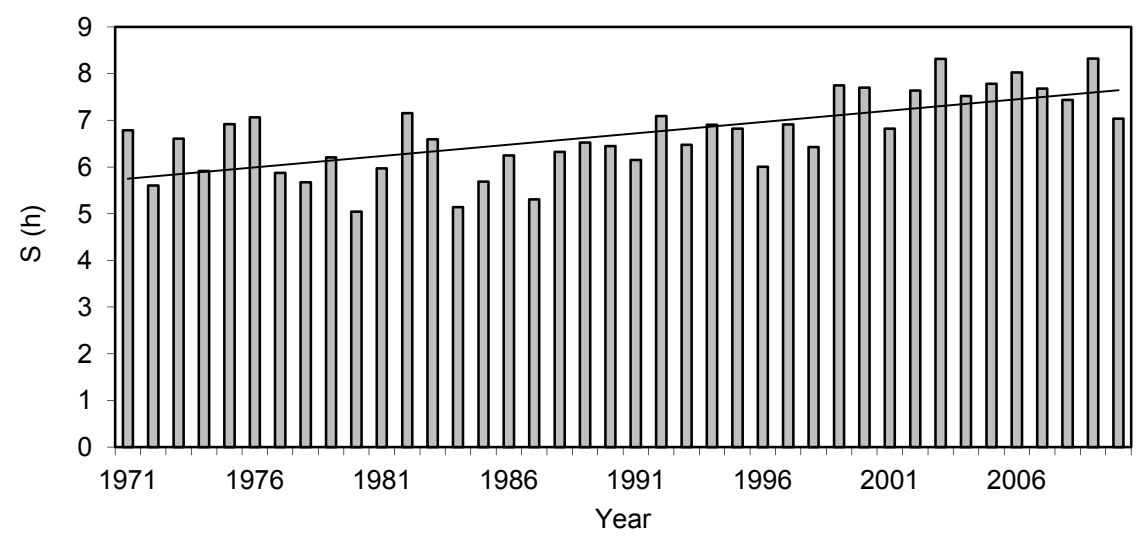

Fig. 9. Linear trend of mean daily sunshine duration S (h) over 18 stations in the growing season (April-September) in 1971-2010. 
investigated to show possible causes of the increase in reference evapotranspiration.

The sum of reference evapotranspiration in the growing season from April to September exceeds $500 \mathrm{~mm}$ in most areas of Poland. Averaged over 40 years and 18 stations it amounts to $504 \mathrm{~mm}$. The monthly sums of reference evapotranspiration, averaged over 18 stations, range from 52 $\mathrm{mm}$ in September to $107 \mathrm{~mm}$ in July.

The spatial variability of reference evapotranspiration was lower than the temporal variability. This means the bigger differentation of the reference evapotranspiration among years than among stations.

As a general rule, reference evapotranspiration isolines as yielded by the Penman-Monteith method showed a characteristic pattern, by decreasing from the central part to the northern and southern parts of Poland as well as to the eastern part. They are traced almost west-east in the central part and north-south in the eastern part. The spatial distribution of reference evapotranspitration in the area of Poland is similar to the spatial distribution of precipitation. The highest reference evapotranspiration was recorded in the region with the lowest rainfall.

The statistically significant linear increasing trends of reference evapotranspiration were determined at each analyzed station in 1971-2010. The increase in the growing season sum of $\mathrm{ET}_{\mathrm{o}}$, averaged over 18 stations, is $30 \mathrm{~mm}$ per 10 years. The significant increase in $\mathrm{ET}_{\mathrm{o}}$ can be explained by the statistically significant increasing trends of air temperature (mean in the growing season by $0.5^{\circ} \mathrm{C}$ per 10 years) and sunshine hours (mean daily sunshine hours by $0.5 \mathrm{~h}$ per 10 years).

In most of the country reference evapotranspiration exceeds precipitation and this is the reason of water shortage for crops. This tendency can be expected to grow with the foreseen climate warming. Future studies should be addressed to answer the question if the area of Poland becomes drier and warmer under predicted climate change in the $21^{\text {st }}$ century and to quantify how predicted climate change will affect reference evapotranspiration, crop water demand, water deficit, water availability, and irrigation water requirements.

\section{Acknowledgements}

The authors would like to thank Mrs. Ewa KaneckaGeszke and Mr. Tymoteusz Bolewski from the Institute of Technology and Life Sciences, Poland, for their help with preparing the meteorological dataset. Data used in this study were made available by the Institute of Meteorology and Water Management, Poland.

\section{References}

1. ALLEN R.G., PEREIRA L.S., RAES D., SMITH M. Crop evapotranspiration - Guidelines for computing crop water requirements. FAO Irrigation and Drainage Paper No. 56. FAO, Rome. pp. 300, 1998.
2. ALLEN R.G., JENSEN M.E., WRIGHT J.L., BURMAN R.D. Operational estimate of reference evapotranspiration. Agron. J. 81, 650, 1989.

3. ALLEN R.G., SMITH M., PERRIER A., PEREIRA L.S. An update for the definition of reference evapotranspiration. ICID Bull. 43, 1, 1994.

4. BUTTAFUOCO G., CALOIERO T., COSCARELLI R. Spatial uncertainty assessment in modelling reference evapotranspiration at regional scale. Hydrol. Earth Syst. Sci. Discuss. 7, 4567, 2010. DOI:10.5194/hessd-7-4567-2010.

5. McVICAR T.R., van NIEL T.G., LI L., HUTCHINSON M.F., MU X., LIU Z. Spatially distributing monthly reference evapotranspiration and pan evaporation considering topographic influences. J. Hydrol. 338, 196, 2007. DOI: 10.1016/j.jhydrol.2007.02.018.

6. SONG Z.W., ZHANG H.L., SNYDER R.L., ANDERSON F.E., CHEN F. Distribution and Trends in Reference Evapotranspiration in the North China Plain. J. Irrig. Drain. E.-ASCE 136, 240, 2010.

7. ALLEN R. G., CLEMMENS A.J., BURT C.M., SOLOMON K., O'HALLORAN T. Prediction accuracy for projectwide evapotranspiration using crop coefficients and reference evapotranspiration. J. Irrig. Drain. E.-ASCE 131, 24, 2005.

8. ALLEN R.G., PRUITT W.O., WRIGHT J.L., HOWELL T.A., VENTURA F., SNYDER R., ITENFISU D., STEDUTO P., BERENGENA J., YRISARRY J.B., SMITH M, PEREIRA L.S., RAES D., PERRIER A., ALVES I., WALTER I., ELLIOTT R. A recommendation on standardized surface resistance for hourly calculation of reference $\mathrm{ET}_{\mathrm{o}}$ by the FAO56 Penman-Monteith method. Agr. Water Manage. 81, (1-2), 1, 2006.

9. FITZMAURICE L., BESWICK A. Sensitivity of the FAO56 crop reference evapotranspiration to different input data. Technical Report QNRM05484. Department of Natural Resources and Mines, Queensland, Australia. pp. 16, 2005.

10. POPOVA Z., KERCHEVA M., PEREIRA L.S. Validation of the FAO methodology for computing $\mathrm{ET}_{0}$ with limited data. Application to South Bulgaria. Irrigation and Drainage. 55, 201, 2006. DOI: 10.1002/ird.228.

11. MAULÉ C., HELGALSON W., MCGINN S., CUTFORTH $\mathrm{H}$. Estimation of standardized reference evapotranspiration on the Canadian Prairies using simple models with limited weather data. Canadian Biosystems Engineering. 48, 1.1, 2006.

12. PALTINEANU C., PANORAS A.G., MAVROUDIS I.G., LOUISAKIS A. Estimating reference evapotranspiration and irrigation water requirements in the Gallikos river basin, Greece. International Agrophysics. 13, 49, 1999.

13. SUMNER D.M., JACOBS J.M. Utility of PenmanMonteith, Priestley-Taylor, reference evapotranspiration and pan evaporation methods to estimate pasture evapotranspiration. J. Hydrol. 308, 81, 2005. DOI:10.1016/j.jhydrol. 2004.10.023.

14. ŁABĘDZKI L., KANECKA-GESZKE E., BĄK B., SŁOWIŃSKA S. Estimating reference evapotranspiration using the FAO Penman-Monteith method for climatic conditions of Poland. In: L. Łabędzki (Editor), Evapotranspiration. Rijeka: InTech. pp. 275-294, 2011.

15. ŁABĘDZKI L., BĄK B., KANECKA-GESZKE E. Magnitude and variability of Penman-Monteith reference evapotranspiration in the growing season of 1970-2004 in selected regions of Poland. Woda-Środowisko-Obszary Wiejskie (Water-Environment-Rural Areas). 12, 2, (38), 159, 2012 [In Polish]. 
16. KOŻUCHOWSKI K., ŻMUDZKA E. 100-year series of aerially averaged temperatures and precipitation totals in Poland. In: Man and Climate in the $20^{\text {th }}$ Century. Studia Geograficzne. 75, 117, 2003.

17. ŁABĘDZKI L. Estimation of local drought frequency in central Poland using the standardized precipitation index SPI. Irrigation and Drainage. 56, 67, 2007. DOI:10.1002/ird.285.

18. TABARI H., MAROFI S., AEINI A., TALAEE P.H., MOHAMMADI K. Trend analysis of reference evapotranspiration in the western half of Iran. Agr. Forest Meteorol. 151, 128, 2011. DOI:10.1016/j.agrformet.2010.09.009.

19. LIANG L.Q., LI L.J., LIU Q. Temporal variation of reference evapotranspiration during 1961-2005 in the Taoer River basin of Northeast China. Agr. Forest Meteorol. 150, 298, 2010. DOI:10.1016/j.agrformet.2009.11.014.

20. VERGNI L., TODISCO F. Spatio-temporal variability of precipitation, temperature and agricultural drought indices in Central Italy. Agr. Forest Meteorol. 151, 301, 2011. DOI:10.1016/j.agrformet.2010.11.005.

21. ESPADAFOR M., LORITE I.J., GAVILÁN P., BERENGENA J. An analysis of the tendency of reference evapotranspiration estimates and other climate variables during the last 45 years in Southern Spain. Agr. Water Manage. 98, 1045, 2011. DOI:10.1016/j.agwat.2011.01.015.
22. BENISTON M., TOL R.S.J. Europe. In: R.T. Watson et al. (Ed.), The Regional Impacts of Climate Change: an Assessment of Vulnerability. A Special Report of IPCC Working Group II. Cambridge University Press:, Cambridge, UK. pp. 149-187, 1998.

23. KĘPIŃSKA-KASPRZAK M., MAGER P., TERLECKA $M$. Variability of selected climatic and hydrological elements in the context of water availability for crops. Infrastruktura i Ekologia Terenów Wiejskich (Infrastructure and Ecology of Rural Areas). 7, 121, 2011 [In Polish].

24. JONAS M., STAEGER T., SCHÖNWIESE C.D. Calculation of the probabilities for the occurrence of extreme events due to climate change - focus Germany. UBA-Forschungsvorhaben 20141254. Institut für Atmosphäre und Umwelt, Universität Frankfurt/Main, Germany. pp 250, 2005 [In German].

25. MLADENOVA B., VARLEV I. Impact of extreme climate years on relative "yield-evapotranspiration" relationships. Journal Water Land Development. 11, 71, 2007.

26. LJUBENKOV I. Water resources of the island of Korčula (Croatia): availability and agricultural requirement. Journal Water Land Development. 17, 11, 2012. 
